\title{
Perceptions of Children in Institutional Sheltering: Interpersonal Relationships and Roles Played
}

\author{
Dalízia Cruz Amaral, Celina Maria Colino Magalhães, Laiane da Silva Corrêa \\ Federal University of Pará, Belém, Brazil \\ Email: celinaufpa@gmail.com
}

Received 15 April 2015; accepted 19 June 2015; published 23 June 2015

Copyright (C) 2015 by authors and Scientific Research Publishing Inc.

This work is licensed under the Creative Commons Attribution International License (CC BY). http://creativecommons.org/licenses/by/4.0/

(c) () Open Access

\section{Abstract}

This article investigates the children's perceptions about their institutional sheltering experiences. Six children from a shelter for children in the region of Belém/Brazil took part in this study. In order to collect the data, it used a form for the categorization of the children, semi-structured interviews, and children's stories. The data collected from the form were tabled to create a general view of the life history of the children and relate them to perceptions learned in the activities with the tales. The interviews were fully transcribed for the content analysis from which were extracted the themes: Reason for sheltering; Reference figures; and Interactions with their families. The main results demonstrate that the children disregard the reason they were sent to the institution; the educators were pointed out as emotional support figures for the children, also situations referring to their experiences in the family context emerge by the reference made to the family and feelings caused by the separation. Therefore, it was possible to discuss, through the children's perception, some questions related to the roles, activities, and interpersonal relationships established in the welcoming environment, as well as some aspects related to the family.

\section{Keywords}

Perceptions, Institutional Sheltering, Children

\section{Introduction}

The custom of welcoming children in sheltering institutions in Brazil has enabled the emergence of an institutionalization culture that is grounded as forms of assistance to the "minor". The way to place children in institutions settled in the past was characterized by the segregation of the social environment, confinement, time con- 
trol, and submission to authority (Rossetti-Ferreira, Serrano, \& Almeida, 2011).

The promulgation of the Child and Adolescent Statute (ECA) in 1990 represents an essential change in the models of assistance, where the child and the adolescent commence to be considered subject of rights at a peculiar condition of development. Even though there is a major distance between what is stated by the law, the judiciary discourse, the Brazilian reality, and the current socio-professional practices, ECA (Brasil, 1990) recommends changes regarding the institutional sheltering services, in an attempt to rupture with the practices of confinement, exclusion, and control so far in practice.

On that account, it is considered that sheltering services may consist in environment to foment the development of children and adolescents, regardless of the time spent in the institution, for they are people in full developmental process (Corrêa \& Cavalcante, 2013). Thus, the sheltering institution is part of the context in which they will develop (Rossetti-Ferreira, Serrano, \& Costa, 2011). In this sense, the child needs to have the right of expressing itself guaranteed and respected as stated by the Technical Orientations for the Sheltering Service for Children and Adolescent (Brasil, 2009).

In Brazil, some studies discuss this perspective of "giving voice" to children (Alves \& Emmel, 2008; Carvalho, 2008; Gabatz, Neves, Padoin, \& Terra, 2010; Garzella \& Serrano, 2011; Marzol, Bonafé, \& Yunes, 2012; Muller, 2014; Silva \& Magalhães, 2011). For a long period of time, according to Thorne (2002), children had their voices silenced and their expectations disregarded. In the research domain, though present, children were considered solely the object of research, nonetheless, that is a changing fact. National and international studies (Mizusaki, 2014; Christensen \& Prout, 2002; Elbers, 2004; Thorne, 2002) consider the child to be a collaborator of the research, with the right to speak.

In this sense, after understanding the human development as a result of the interaction between the person in development and the environment of which it is part, this research brings the systemic perspective of Bronfenbrenner (1996, 2011). It is focused, especially, on the microsystem aspect. In other words, investigating the perceptions children have about their sheltering experience with their patterns of activity, roles, and interpersonal relationship, which emerged from the children's report, it was considered the microsystemic dynamic.

In the immediate context (microsystem), as formulated by Bronfenbrenner (1996), what "matters for the behavior and the development is the environment as it is perceived" (p. 6). In this direction, it is considered the children's active role along the development. Therefore, it is relevant to investigate the perception they have about their own sheltering experience as described by Bronfenbrenner $(1996,2011)$, besides the objective characteristics of the context, reality must be considered as it exists in the subjective world of the person.

Therefore, the current research aimed at investigating the children's perceptions about their sheltering experience, through a theoretical reference that approaches the physical and social aspects of the context. Thus, it takes into consideration how the developing person experiences such aspects in the dynamic of the interactions established with objects and symbols present in the institution.

\section{Method}

\subsection{Design}

This study is a qualitative research for bringing the natural environment as direct source of data and the researcher as an essential instrument. Besides, it presents a descriptive character, in which it was considered the child's perception about its sheltering experience. As a result, this is an investigation used to uncover perceptions and opinions, products of the interpretations people make about how they live, how they feel and think (Minayo, 2010).

\subsection{Participants}

Six children of both genders (five girls and one boy), six years old, that were welcomed in a state institution for children in the biggest capital in the North of Brazil. The inclusion criteria to partake in the study was: 1) be in the institution for at least a month; 2) age between six and seven years old; 3) absence of any type of disorder; and 4) acceptance to take part in the study.

\subsection{Contextualization}

The institution is placed at the metropolitan region of Belém, state of Pará-Brazil, and it attends children aging 
from zero to six years. It welcomes 50 children in average a month, and had by the time of the data collection 102 educators, among those on duty and on day shift. The children were dispersed in seven dormitories according to age criteria.

The place used for the data collection was a room from the education department of the institution. For the story telling the chairs were arranged in circles in order to ease the visual contact of the researcher with the children, and theirs with the story.

\subsection{Instruments and Materials}

A form for the characterization of the children adapted from Cavalcante, Magalhães and Reis (2014) was used, composed by theme axis: child identification (17 items), family situation (nine items), institutionalization process (27 items), and health (19 items). However, to achieve the research objectives the socio-demographic data of the children and their families were used. Six children stories were used: When I Feel Angry, The Three Little Pigs, The Ugly Duckling, Where the wild things are, A mother for Choco, Everybody feels: happy, chosen by the following criteria: 1 ) adequate reading, considering the content of the history and the children's age; 2) plot that enables the discussion of the children's experiences in the shelter, as well as feelings of rage, happiness, sadness, and anguish; 3) tale, due to the short time.

In addition, six semi-structured interview scripts were used, created by the researcher to obtain information about the children's perception regarding their sheltering experience. For every story telling activity a script with questions was created, making reference to specific parts of the narrative, in order to connect the ideas, using questions coherent to the plot.

Finally, it was adopted the field diary that allowed the researcher to log her perceptions about the ecologic environment where the activities took place. As materials it was used a camcorder to record the story telling, and paper and pen for the researcher to take notes.

\subsection{Procedure}

The data were collected in two periods: 1) filling out the forms for the children characterization; 2) in the story telling activities through interviews. The characterization of the participants was done through documental research with access to the individual charts of the children, important documents where the personal and institutional history of the sheltered was logged, provided by the technical staff of the institution.

The activities with the stories were performed in seven days, each meeting corresponded to telling one story and the interviews were carried out. The time spent on each activity was 15 minutes in average. Both the story telling and the interview were performed by the researcher. The interviews were done as a conversation while the stories were being told.

Therefore, in the first meeting, the children were asked to chose the name of a character they would be identified by in the research. Each meeting was organized in three moments: 1) the children were taken to the room where the activity would happen, there was some time for them to organize themselves and for setting up the camcorder; 2) next (from the second meeting on) the children were asked to talk about the story from the previous day; 3 ) then the researcher would present the story to be worked with, started telling the story, and made the interviews. It is noteworthy to say the seventh day was necessary so the children could talk about the story told on the sixth day as well as making an evaluation of the activities.

\subsection{Data Analysis}

The information logged in the characterization form were organized in a table so it would allow a broad view of the history of life of these children, besides relating it to their perceptions captured from the activities with the stories. The information that received more attention were the ones in reference to the reason for and time of sheltering, visitations, education, and socio-family situation.

The interviews were fully transcribed for the content analysis, for that it was used the Bardin (2011) technique, which consists of a set of communication analysis techniques in order to systematically and descriptively infer about the contents of the message. In this sense, the data organization was performed through semantic categories that emerged from the children's discourse, represented by themes: reason for sheltering, figures of reference, and interaction with the family. 
The category Reason for sheltering gathers the children's verbalization that referred to the knowledge of why they were in the institution. Figures of reference gathers the verbalizations that identified people they had emotional bonds (adult and/or other children). The category interaction with the family highlights the reports that alluded situations experienced in the family of origin.

\subsection{Ethics Considerations}

The research project "Perceptions of children in shelters: environments and relational forms" to which this project is linked, was submitted and approved under the No. 146/11 by the ethics committee in research with human beings from the science and health institute of the Federal University of Pará CEP-ICS/UFPA, in addition with the consent from the legal representative of the institution and from the childhood and youth court.

In order the preserve the children's identity their names were replaced by famous characters chosen by the children on the first day of data collection. Moreover, as it is a study that involves children and emotional and delicate contents, two psychologists from the institution were invited to take part in the data collection, as a way to guarantee a specialized attendance/welcoming in case of emotional mobilization by the children.

\section{Results and Discussion}

The data is presented in two axis: the children's characterization, and the categories extracted from the interviews performed along the activities with the stories.

\subsection{Characterization of the Children: Protagonist of This Story}

The children that participated in this study were from socioeconomically unfavorable families. Table 1 illustrates the data according to the characters chosen by the children and their personal and institutional characteristics.

Among the reasons for sheltering it is observed that the data found in this population confirm national studies' data, as the ones found in Brasil (2013), in which the main reasons for sheltering were negligence of parents and/or responsible, abandonment by the parents and/or responsible, and domestic violence. Regarding the period of sheltering it is noted that the children are less than two years in the institution, respecting the maximum period of two years that a child should stay in the institution proposed by the Law 12.010 (Brasil, 2009). It is noteworthy to say that this maximum period for sheltering must be taken into consideration for the prolonged effects on the development of children and adolescents that live in such conditions.

With regards to the attendance of these children to school and visitations, the institution granted the children the right to live in contact with the family and community according to what is stated by the ECA (Brasil, 1990) and the Technical Orientations (Brasil, 2009), for all the children that partook in the study received visits from the family and were enrolled in the education system.

With reference to the profile of the families that the children lived before being sheltered, Barbie, Bela, and Snow White lived with their mothers, Cinderella with her mother, stepfather, and maternal grandmother, Little Red Riding Hood lived with the maternal grandmother and her partner. There was no information in the Police's

Table 1. Children's identification, personal and institutional characterization.

\begin{tabular}{|c|c|c|c|c|c|c|}
\hline Name & Gender & Age & Sheltering period & Reason for sheltering & Attends school & Is visited by who? \\
\hline Barbie & Female & Six & 1 Month/7 days & Abandonment & Yes & Mother \\
\hline Bela & Female & Six & 1 Month/28 days & $\begin{array}{l}\text { Risk situation-with body } \\
\text { injury }\end{array}$ & Yes & Mother \\
\hline Snow White & Female & Six & 1 Month/28 days & Physical Violence & Yes & Bela's Mother \\
\hline Cinderella & Female & Six & 1 year/38 days & Abandonment & Yes & $\begin{array}{l}\text { Mother and materna } \\
\text { grandmother }\end{array}$ \\
\hline $\begin{array}{l}\text { Little Red Riding } \\
\text { Hood }\end{array}$ & Female & Six & 6 months/28 days & $\begin{array}{l}\text { Abandonment and family } \\
\text { negligence }\end{array}$ & Yes & $\begin{array}{c}\text { Mother and materna } \\
\text { grandmother }\end{array}$ \\
\hline Police & Male & Six & 2 months/13 days & Abandonment & Yes & Mother \\
\hline
\end{tabular}


chart about who he lived with before the sheltering. About the socio-economic level of the families, the monthly income was between R\$20,300 and R \$ 40,000; two of the families received benefits from the government: Bolsa Família and Bolsa Auxílio. Regarding education and job occupation of the legal representative of the children: two mothers had finished high school, one didn't finish it, and two grandmothers hadn't finished elementary school. About their occupations, three mothers and one grandmother worked with domestic services, one was unemployed, and the data of the other was incomplete.

Therefore, it was noted a family environment with the prevalence of the female figure, either mother or grandmother, supporting the children before the sheltering, which reinforces the new family configurations in the national scenery, in agreement with Muller (2014). It is also identified that the families are vulnerable, with low income and education, what may configure a risky scenery for the children.

\subsection{Children's Perceptions}

The perceptions extracted from the activities brought up three themes in reference to the sheltering experience: Reason for sheltering; Figures of reference; and Interaction with the families.

\subsection{Reason for Sheltering}

When asked about the reason they were sheltered the children responded differently, as showed by episode 1 , taken from the activity with the tale "The Three Little Pigs"

Researcher: (...) What about you? Why do you think you are here in the shelter? Why do you come here? Little Red Riding Hood: I'm here because I stayed on the streets. (...) Snow White: raises the shoulders and makes gestures indicating not knowing why. Researcher: Don't you know Snow White? Snow White: moves her head from the right to the left indicating denial. Barbie: I know. Researcher: Do you know Barbie, why? Barbie: Advice from my grandmother. Researcher: What about you Police, why are you in the shelter? Hum? Police: caress the hand of the Social Assistant, smile, lowers his head and his sight, demonstrating shyness, and looks back to the educator. Educator: looks at Police and says in a tender tone of voice: you can say it! Snow White: (smiling) says: because he was stolen.

Episode 1 illustrates the verbalizations that indicate knowledge and ignorance about the reason that brought them to the institution. Both Snow White and Police responded in a non verbal manner. The way Snow White responded, shaking the head to the right and to the left indicating denial suggests unawareness of the reason for sheltering. On its turn Police, contrasting with the character he chose that represents authority/power, looks at the educator as requesting authorization to speak. The educator speaks in a tender tone of voice when he looks at her. She also tries to look at him in a tender and approving way, verifying a certain verticality in the relationship.

Marzol et al. (2012) emphasize the importance of reciprocity as an important element of interpersonal relationships and thus for human development, since the child, as a product of a culture, must be understood as a subject that also produces culture, leaving their mark actively with peculiar characteristics biopsychosocial (Mizusaki, 2014).

Accordingly, it was observed that Police was sheltered for a little longer than two months, in other words, he was still in the process of adapting to the institution's routine, establishing new interpersonal relationship and change of roles. For that reason it can be said that the entrance to a sheltering institution that becomes the microsystem of this child is an important ecological transition. Therefore, there are important changes in the structure of relationships, in the activities performed, and in the roles played as stated by Bronfenbrenner (2011). Hence, the institution becomes a part of the child's history, the affective relationship built will become part of its psychological field, so it cannot be removed from the child's life for it has an essential role in its subjective constitution and is already part of its mental ecology.

Bronfenbrenner (2011) considers, yet, that children are active participants and have influence on the course of their development, they must not be seen as inserted in certain contexts, though as part of them. "The processes and results of the human development" (Bronfenbrenner, 2011: p. 145) are articulated with the characteristics of the environment and the person. In this sense, it is crucial for the caretakers of the sheltered children to be qualified to deal with delicate situations as this one of informing the child the reason it is sheltered.

Therefore, based on how the participants responded, it was verified the importance of the dialog between the educators, technicians, and the children in reference to the real reason they are in the institution. With regards to the specific protection measures, the ECA (Brasil, 1990) denotes this information is mandatory. It also adds the 
right to speak and to be heard whenever they feel the need. This must be part of the routine of children in shelters, who must have their personal experiences considered, for the way they signify and internalize the experience of separation from the family through subjective characteristics and the quality of proximal processes, established lasting between biopsychological body, people, objects and symbols (Lisboa \& Koller, 2004; Cavalcante \& Silva, 2010).

It was also observed that Little Red Riding Hood and Barbie affirmed to know the reason they were sheltered. However, only the answer given by Little Red Riding Hood is close to the reason stated in her chart (abandonment and family negligence). Barbie, on the contrary, said she was in the institution because of an advice from her grandmother, which makes us think about a concealment, an abstraction of the real reason that took her to the institution. That's why the professionals engaged with the care and development of these children must become conversation partners (Corrêa \& Cavalcante, 2013) and help them understand and (re)signify themselves, the world, and the experiences they live (Garzella \& Serrano, 2011; Ortín, 2012).

Nonetheless, to achieve quality in the attendance it is crucial to invest in the qualification and monitoring especially of professionals that are in direct contact with the children and the families. That is a complex tasks that needs a team with adequate technical knowledge (Brasil, 2009).

It must be highlighted the statements of Snow White and Barbie that associate the reason for sheltering to the fact that they were stolen. It is noted that their speech is taken by a very strong symbolic load, the idea of theft, abrupt withdraw, that is possibly part of their imagination reflecting on the perception they have about the reason why they are in the institution. Therefore, it is important the professionals are aware of how these children adapt to their torments and doubts. Because, if it is not clear to them why they are away from home, the role of the institution as an encourager of the development weakens as long as it doesn't inform the child of the real reason they were taken from their family, as well as their perspective of going back.

\subsection{Figures of Reference}

The results reveal the educators are the ones to give emotional support to the children. In Episode 2, extracted from the story "When I fell angry" the children named some educators they talked with when they were angry.

Barbie: Hey aunt (talking to the researcher), did you know when someone does something to me I tell aunty? (referring to an educator of the institution). Researcher: Barbie, do you talk to anyone when you're angry? (...). Barbie: I talk to the aunty. Researcher: Who is the aunty? What is the name of the aunty you talk to? Barbie: Aunt Rachel. (...) Researcher: Is it aunt Rachel? And you Bela? Bela: With Aunt Anastácia. Researcher: Is it with her you talk to when you're angry? And Police, is there anybody you talk to when you're angry? (Police laughs). Cinderella: I talk to aunt Ana. (...)

In Episode 2 the children name the educators as the people they talk to when they are angry. These data diverge from the results of the research performed by Silva and Magalhães (2011), in which the participant had difficulties to talk about the institution, using elements from school to characterize it, thus referring to the educator as teachers; also pointed out from the results of Garzella and Serrano (2011), in which the children appeared to have difficulties to point out important people in the institution. On the other hand, these data corroborate the findings of Marzol et al. (2012), in which the participants mentioned the caretakers as reference figures. The authors point out that children and adolescents experience a feeling of protection through a dialog/ conversation.

Welcoming and protecting are relevant attitudes for children to establish relationship and positive bonds in the institution environment. According to Marzol et al. (2012), the caretakers are committed to observe in children and adolescents the reactions, behaviors, and/or signs of anguish, anxiety, and happiness, for they are the ones to spend more time with them. Thus, the caretakers must adopt care practices that makes possible the dialog, facilitating the feelings to be elaborated by the children.

Bela, who mentioned the educator Anastácia as the person she talked to when she felt angry, showed to be comfortable to communicate with other educator that was present in the activity where the story "The Three Little Pigs", as seen in episode 3.

Researcher: Really? (the children spoke at the same time). What about you Bela, where would you hide? (while the other children reply aloud, Bela turns to the educator present and speaks to her ear). Where you told aunt Emília (educator)? Bela hugs the educator, hiding her face in her chest, indicating shame. Researcher: Where Emilia, she told you she would hide? Educator: under the bed. 
With that illustration, it is possible to ponder about the importance of creating spaces and moments that offer opportunities for the expression and setting of new bonds and favor the formation of primary dyads and affective relationship for the promotion of development. According to Bronfenbrenner (1996), at the rate the people get involved in dyadic interactions it is likely to be developed more expressive feelings from one relationship to another. Such feelings may be either reciprocally positive, negative, ambivalent, or asymmetric. The formation of this type of dyad have strong influence on the motivation for learning and in orienting the course of development (Bronfenbrenner, 1996).

Another important issue is the maternal image projected in one of the educators. When asked about who could be the character's mother in the story the educator that was being part of the activity was indicated by Police, according to episode 4, in which the story told was “A mother for Choco".

Researcher: Who could be his (the character's) mother? Police: Aunt Vivinha (educator). Researcher: Why

Police, she could be his mother? Cinderella: Aunt Vivinha is going to the story. Police: Just because, be-

cause he would stay in her house.

It is noteworthy that the educator mentioned was seen by other professionals of the institution as an excellent educator, for she treated the children with affection and always organized activities with them on the weekends as barbecues, with the intention to make their day more likely to those experienced in a family environment. Moreover, the educator brought her daughter to spend the day in the institution and let her free, playing with the children. In addition, during the data collection, her daughter's birthday was celebrated in the institution with the children who had birthday in the same month (notes in the field diary).

Guará and Gulassa (2011) wrote that sheltered children may be temporarily more protected and disclose new support systems for their development when their primary care context, the family, cannot fulfill their needs and guarantee a healthy development. The authors believe it is possible an intentional planning of the daily routine in order to favor the experiences of living in a group and in a cooperative way, minimizing the natural rigidity of the institutional care.

According to the data from this study, the mother role designated to the educator may also be associated to how she treats the children. This suggests that being a mother to these children may be related to how they are cared for and that duties are the responsibility of a good mother, the episode 5 illustrates this situation.

Researcher: Do you think she (the character of the story) would be a good mother for Choco? Children:

Yes. Researcher: What is to be a good mother? Barbie: Take good care of him. Snow White: Buy food for her son... toy for him.

It is observed that the perception Barbie and Snow White have about what is to be a good mother is related to the matters of care and attention to food and toy. In the study performed by Gabatz et al. (2010), through the report of the children that took part in the research, the care can be understood in several ways: concern attitude, care display, affection and zeal for the other. The authors add, yet, that identifying the meaning of care for children and adolescent may enable the understanding of how certain societies live, the contemplation about the essential human values of these societies and set action goals to transform reality.

Episode 5 leads to the reflection on the importance of promoting and maintaining new bonds in the institution through the creation of opportunities for coexistence, where the children can share stories, experiences, care, affection, and everything that can feed a relationship (Rossetti-Ferreira et al., 2011).

In the research made by Rosa, Santos, Melo and Souza (2010), the authors observed the good relationship between the children and their caretakers, with consequent positive attachment relationship, understood as the desire and the need children have for proximity and contact with a specific figure, for example the caretaker. This result converges with the Marzol et al. (2012), in which the caretaker figure was evidenced by the participants (children and adolescents welcomed) as a key element in the network of support and affection. In this sense, it is possible that children and adolescents in care develop in a healthy way, provided they are inserted into relational context responsive and sensitive to their social and emotional needs (Marzol et al., 2012).

Brasil (2009) points out the value of the educator/caretaker as important references for the development, however it clarifies that it must be sure about its role. It may be created an affective bond to the sheltered children/ adolescent and contribute to the construction of a family environment, with the attention not to "possess" the child or the adolescent, or to compete and diminish the family, whether the original or a surrogate. 


\subsection{Interaction with the Families}

This category emerged from the reports of children that talked about situations experienced in family. Even though children in institutional shelter are away from their families, they are still present in their memories and the institution must stimulate the interaction, as well as make efforts in order to place them back in the family context. In this sense, the family appears as an important theme in the perception of the children, the reference to it and feelings brought up by the separation are considered in the sheltering experience.

Upon that, on the first day of activity, when the story told was "When I feel angry...", the children were asked what they did when they were angry and Snow White and Little Red Riding Hood had similar answers: the first said that when she was angry she drank cachaça (Brazilian alcoholic beverage made from sugar cane); the second, right after her, sad she drank "some beer" (note on the field diary).

The speeches of Snow White and Little Red Riding Hood, from the story told, suggest contents in reference to personal experiences. They reveal situations that probably both lived in their family environment. It is important to mention that on Snow White's chart there is the information that her mother was addicted to alcohol.

Such results corroborate the findings of Alves and Emmel (2008). As mentioned by the authors the participants expressed the impact of the stories told in different ways during the symbolic activity, for it was observed that some stories made possible for some contents related to the children experiences and conflicts to come to surface.

The findings of Carvalho (2008) also showed that the narrative seemed to reveal in the children some structures known from the adults world, elements that probably brought up experiences from their daily routine. In this sense, Cinderella's speech in episode 6 reveal a possible identification with part of the story told.

Researcher: When he is angry he also goes to his favorite place. Where is that place? Cinderella: In the tree. Researcher: Where do you go when you are angry? Where do you like to stay when you are angry? (the children are agitated, speaking all at the same time, Cinderella asks for them to talk one at a time) Cinderella: One at a time, one at a time (...). Hey aunt, when I'm at home and my mom gets angry I run from her and climb the tree very quickly, when she calls me I don't get down.

Similarly, it was also noted on Police's speech an identification with a part of the story "Where the wild things are" according to episode 7.

Researcher: So, remember when the aunt asked you where you would go if you had a little boat like Max's, remember? (...) Researcher: (...) And when you'd come back from the end of the sea? (...) Police: I'd go to my grandmother's house that is near there. Researcher: Near there, right Police? Police: Yeah (laughs and lower the head, indicating shame).

From these extracts it is possible to affirm, according to Guará (2010), that behind the history of every child there are always the family's histories. Family is a context of living and confrontation between genders and generations, there coexist situations of conflicts and mechanisms of solidarity in the relationships (Vitale, 2010) and also affection. The speeches of Cinderella and Police, to that effect, corroborate the results of Muller (2014), in which the children narrate different situations of interactions with their mothers, especially from when they lived with them.

On the day the story told was "Everybody feels: happy", Snow White also referred to her family environment, as shown in episode 8.

Researcher: Let's see, then, what was there in Julia's party, so look (Snow White asks to talk), talk Snow White. Snow White: (she speaks at the researcher's ear). Researcher: Really? That's nice! Look, on Snow White's birthday her mother bought a thousand cakes, let's see what happened to Julia. Police: She said it. Snow White: She looks at Police and confirms with the head.

It was observed on Snow White's speech a positive perception of experiences with the mother, although structured by a hyperbole (bought a thousand cakes) and suggests perceptive aspects of real and/or ideal care that she receives. The idealization of family relationships is very common in children in residential care, this can be understood as a process of adaptation and restoration of young people to retrieve the fragile family relationships (Siqueira, Abaid, \& Dell'Aglio, 2012). To Bronfenbrenner (1996), the roles played by a person tend to evoke perceptions, attitudes, and patterns of relationship. Hence the importance of considering that contents 
from imagination and idealization may be present in the perceptions evoked by the roles played.

Because of that, the institution must be aware of how the children perceive the care roles played by the family. It is a subjective way they have to see and comprehend the context they establish their interpersonal relationship, play their roles, and the roles played by other important people from their ecological environment.

The results above-mentioned reveal the importance of analyzing the reality of the child along with its family's, considering the historic-social and economic scenery that mark and involve several actors and their development (Rossetti-Ferreira, Almeida, Costa, Guimarães, Mariano, Teixeira, \& Serrano, 2012).

On Muller (2014), the mothers were the most recurrent family reference in the children's narratives. likewise, in this study, the children would make reference to situations lived with their mothers and also with their grandparents, on Police's case. According to the author, from the macro structural point of view, the mothers are in accordance with the Brazilian statistical data regarding the monoparental family model. From the relational point of view the mothers/grandmothers are the ones to visit the children, searching for different strategies to make possible to reallocate the children in the family. In agreement with this affirmation, the mothers and maternal grandmothers were the ones to visit the children that were part of this study.

According to the exposed, it was verified the importance for the strengthening of the family bonds to take place in the daily activities of the sheltering services, such as the visits and family meetings. Therefore, an important step in supporting the recovery of the protective capacity of the family is for the professionals to respect it (Guará, 2010). This respect is demonstrated by activities done in order to favor the contacts that encourage or rebuilt the bonding of the child and its family.

Many times the families of sheltered children are marked by exclusion, violence, and suffering. As seen before, the families these children used to live before the sheltering were socio-economically unfortunate, being found in a condition of vulnerability. It is essential, to that matter, to consider the family relationships to be part of a socio-historical period, for not having the risk of their subjectification, crystallizing them as violent, negligent, unstructured, etc. One must pay attention to the way the families of these children are signified by the professionals of the sheltering institution, according to Brasil (2009).

In fact, the developmental potential of an institution is not only present in the work developed with the children, but also with their families, as stated by Bronfenbrenner (2011), the need for supporting the family and the care with the child is related to how the family works and the circumstances they live in.

\section{Conclusion}

The deeds made by the sheltering institution to attend children and adolescents were for a long time characterized by subordination, control, segregation, and submission. This line of work was guided by conceptions that understood childhood and adolescence as phases of development without the conditions to give opinions about the decisions made about their lives.

However, the ECA (Brasil, 1990) and the technical orientations (Brasil, 2009) represent a rupture with traditional conceptions, changing the notion of childhood and youth, now seen as subject of right, proposing the participation of the children and adolescents, as well as their families, in the matters of their lives.

In this sense, to investigate the children's perceptions about their sheltering experiences, it seized up aspects relating to (un)knowledge these children about the reasons for sheltering, the established interactions in the institution between them and educators as reference figures, as well as aspects of their interaction with their families. Thus, through the systemic perspective of Bronfenbrenner (1996, 2011), it was possible to discuss issues related to roles, activities, and interpersonal relationship established in this microsystem, as well as those in reference to the family.

It is important to create moments for the child to speak when it feels the need, for in the institution there are no adequate places or moments for them to be heard. Besides, this study brings in its body of data-the speech/ perception of the children - aspects of the care given to them in the institution, which contributes for the decisions raised by the technical orientations (Brasil, 2009) and by ECA (Brasil, 1990). Hence it is important to develop researches that make the child a collaborator and at the same time an active subject in the process of hearing, for the fact that they may indicate how the institution can organize its actions and relations in its favor, changing, thus, the role that was attributed to the child in this context.

It is suggested that new studies perform the activities of storytelling with a greater amount of stories so more perceptions can be apprehended. Moreover, it should make use of other age ranges and longer period of shelter- 
ing for making comparisons within groups. With reference to the limitations of this study, it was found a major difficulty in the access and control of the children's chart, especially regarding information about the profile of the families.

\section{References}

Alves, H. C., \& Emmel, M. L. G. (2008). Abordagem bioecológica e narrativas orais: Um estudo com crianças vitimizadas. Paidéia, 18, 85-100. http://dx.doi.org/10.1590/S0103-863X2008000100009

Bardin, L. (2011). Análise de conteúdo. São Paulo: Edições.

Brasil, Conselho Nacional dos Direitos da Criança e do Adolescente e Conselho Nacional de Assistência Social (2009). Orientações técnicas para os serviços de acolhimento para crianças e adolescentes. Brasília: Conanda.

Brasil, Conselho Nacional do Ministério Público (2013). Um olhar mais atento aos serviços de acolhimento de crianças e adolescentes no país. Relatório da resolução no. 71/2011. Brasília: Conselho Nacional do Ministério Público.

Brasil, Estatuto da criança e do adolescente-ECA (1990). Diário Oficial da União. Lei no. 8.069, de 16 de julho de 1990. Brasília, DF.

Bronfenbrenner, U. (1996). A ecologia do desenvolvimento humano: Experimentos naturais e planejados. Porto Alegre: Artes Médicas.

Bronfenbrenner, U. (2011). A bioecologia do desenvolvimento humano: Tornando os seres humano mais humano. Porto Alegre: Artes Médicas.

Cavalcante, L. I. C., Magalhães, C. M. C., \& Reis, D. C. (2014). Análise comparativa do perfil de crianças em acolhimento institucional nos anos de 2004 e 2009. Psico, 45, 90-99. http://dx.doi.org/10.15448/1980-8623.2014.1.13180

Cavalcante, L. I. C., Silva, S. S. da C., \& Magalhães, C. M. C. (2010). Institucionalização e reinserção familiar de crianças e adolescentes. Mal-Estar e Subjetividade, 10, 1147-1172. http://pepsic.bvsalud.org/pdf/malestar/v10n4/05.pdf

Carvalho, C. (2008). Um olhar sobre o abrigamento: A importância das histórias infantis em contexto de abrigo. Dissertação não publicada, Uberlândia, SP: Universidade Federal de Uberlândia.

Corrêa, L. S., \& Cavalcante, L. I. C. (2013). Shelter Educators: Conceptions on Development and Care Practices in Play Situation. Journal of Human Growth and Development, 23, 309-317.

http://www.revistas.usp.br/jhgd/article/view/69506/72074

Christensen, P., \& Prout, A. (2002). Working with Ethical Symmetry in Social Research with Children. Childhood, 9, 477497. http://dx.doi.org/10.1177/0907568202009004007

Elbers, E. (2004). Conversational Asymmetry and the Child's Perspective in Developmental and Education Research. International Journal Disability, Development and Education, 51, 201-215. http://dspace.library.uu.nl/handle/1874/11219 http://dx.doi.org/10.1080/10349120410001687409

Gabatz, R. I. B., Neves, E. T., Padoin, S. M. M., \& Terra, M. G. (2010). Fatores relacionados à institucionalização: Perspectivas de crianças vítimas de violência intrafamiliar. Revista Gaúcha de Enfermagem, 51, 670-677.

http://seer.ufrgs.br/RevistaGauchade Enfermagem/article/view/12913

Garzella, M. C., \& Serrano, S. A. (2011). O abrigo sob as lentes das crianças: Olhares e vozes sobre a convivência na instituição. In M. A. Rossetti-Ferreira, S. A. Serrano, \& I. G. Almeida (Eds.), O acolhimento institucional na perspectiva da criança (pp. 199-234). São Paulo: Hucitec.

Guará, I. M. F. R., \& Gulassa, M. L. (2011). Prefácio. In M. A. Rossetti-Ferreira, S. A. Serrano, \& I. G. Almeida (Orgs.), O acolhimento institucional na perspectiva da criança (pp. 11-17). São Paulo: Hucitec.

Guará, I. M. F. R. (2010). Abrigo-Comunidade de acolhida e socioeducação. In M. V. Baptista (Org.), Abrigo: Comunidade de acolhida e socioeducação (pp. 59-72). São Paulo: Instituto Camargo.

Lisboa, C., \& Koller, S. H. (2004). O microssistema escolar e os processos proximais: Exemplos de investigações científicas e intervenções práticas. In S. H. Koller (Eds.), Ecologia do desenvolvimento humano-Pesquisa e intervenção no Brasil (pp. 337-354). São Paulo: Casa do Psicólogo.

Marzol, R. M., Bonafé, L., \& Yunes, M. A. M. (2012). As perspectivas de crianças e adolescentes em situação de acolhimento sobre os cuidadores protetores. Psico, 43, 317-324. http://revistaseletronicas.pucrs.br/revistapsico/

Mizusaki, R. A. C. (2014). Vozes infantis: Compreendendo o que as crianças nos ensinam sobre o que sabem das relações de gênero. Educa-Revista multidisciplinar em educação, 1, 99-115. http://www.periodicos.unir.br/index.php/EDUCA/article/viewFile/1099/1215

Minayo, M. C. S. (2010). O Desafio do Conhecimento: Pesquisa qualitativa em saúde. São Paulo: Hucitec/Abrasco.

Muller, F. (2014). Perspectivas de crianças acolhidas institucionalmente sobre suas famílias de origem. Linhas Críticas, 20, 125-145. http://periodicos.unb.br/index.php/linhascriticas/article/view/9335 
Ortín, L. R. (2012). El educador social: Ética y prática profesional. Revista Interuniversitaria, 19, 51-63. http://www.redalyc.org/articulo.oa?id=135025474004

Rossetti-Ferreira, M. A., Serrano, S. A., \& Almeida, I. G. (2011). A criança e o adolescente como sujeito ativo e de direitos no processo de acolhimento institucional: uma longa história ainda inacabada. In M. A. Rossetti-Ferreira, S. A. Serrano, \& I. G. Almeida (Orgs.), O acolhimento institucional na perspectiva da criança (pp. 29-59). São Paulo: Hucitec.

Rossetti-Ferreira, M. C., Almeida, I. G., Costa, N. R. A., Guimarães, L. A., Mariano, F. N., Teixeira, S. C. P., \& Serrano, S. A. (2012). Acolhimento de Crianças e Adolescentes em Situações de Abandono, Violência e Rupturas. Psicologia: Reflexão e Crítica, 25, 390-399. http://dx.doi.org/10.1590/s0102-79722012000200021

Rosa, E. M., Santos, A. P., Silva, C. R., \& Souza, M. R. (2010). Contextos ecológicos em uma instituição de acolhimento para crianças. Estudos de Psicologia, 15, 233-241. http://dx.doi.org/10.1590/S1413-294X2010000300002

Silva, F. L., \& Magalhães, L. A. (2011). “Assistir Robocop lá é chato!” conversando com crianças sobre suas vivências no abrigo institucional. In M. A. Rossetti-Ferreira, S. A. Serrano, \& I. G. Almeida (Orgs.), O acolhimento institucional na perspectiva da criança (pp. 235-272). São Paulo: Hucitec.

Siqueira, A. C., Abaid, J. L. W., \& Dell'aglio, D. D. (2012). Famílias e instituições de acolhimento-Interfaces entre risco e proteção. In L. F. Habigzang, \& S. H. Koller (Orgs.), Violência contra crianças e adolescentes: Teoria, pesquisa e prática (pp. 176-189). Porto Alegre: Artmed.

Thorne, B. (2002). From Silence to Voice: Bringing Children More Fully into Knowledge. Childhood, 9, 251-254. http://dx.doi.org/10.1177/0907568202009003604

Vitale, M. A. F. (2010). Famílias: Pontos de reflexão. In M. V. Baptista (Org.), Abrigo: Comunidade de acolhida e socioeducação (pp. 73-83). São Paulo: Instituto Camargo. 